\title{
Journal of Librarianship and Scholarly Communication
}

\section{Pubrarians and Liblishers at 20: Reflections on Library Publishing from 1995-2014}

John Unsworth

Unsworth, J. (2014). Pubrarians and Liblishers at 20: Reflections on Library Publishing from 1995-2014. Journal of Librarianship and Scholarly Communication 2(4):eP1201. http://dx.doi.org/10.7710/2162-3309.1201

(C) 2014 by the author(s). This open access article is distributed under a Creative Commons Attribution License, which allows unrestricted use, distribution, and reproduction in any medium, providing the original author and source are credited.

JLSC is a quarterly journal sponsored and published by Pacific University Library | ISSN 2162-3309 | http://jlsc-pub.org 


\title{
LIBRARY PUBLISHING FORUM 2014
}

\section{Pubrarians and Liblishers at 20: Reflections on Library Publishing from 1995-2014}

\author{
John M. Unsworth \\ Vice Provost, University Librarian, Chief Information Officer, Professor of English \\ Brandeis University
}

The following is a lightly edited transcript of the opening keynote address delivered March 5, 2014 at the inaugural Library Publishing Forum in Kansas City, Missouri.

Good morning. I'm looking back in this talk to a talk that I gave in 2005 at a meeting of the Society for Scholarly Publishing in Boston. As I was sitting and thinking before I got up here, I'd say my interest and involvement in the subject of library publishing and the many things it can mean began another 10 years before that, around 1995.

At that point, I was the director for the Institute of Advanced Technology and Humanities. I had started there in 1993 when they hired me by mistake. I was working with the Rossetti Archive and negotiating with Eve Trager and some other people at the University of Michigan Press to make the Rossetti Archive one of the University of Michigan Press's first electronic publications. That was a long negotiation, and it did not result in a publication. The experience was tutelary, to say the least.

I maintained an interest from that time forward in trying to figure out the proper relationships and collaborations for librarians, scholars, and publishers, especially around new forms of digital scholarship. I'll be talking about some of those topics today, nearly twenty years later. Hopefully, a little bit of wisdom will have accrued in the interval.

Correspondence: John M. Unsworth, Brandeis University, Waltham, MA 02454, unsworth@brandeis.edu 
Some of the things we have to negotiate in this territory have to do with professional identity and how we think of ourselves in our professions. The last time I talked about this, I invented not only one, but two, new professions: "liblisher" and "pubrarian." Interestingly, "liblisher" hasn't caught on. Nobody wants to be one of those, so "pubrarians" it is.

The question of professional identity has intersected for me, just recently, in the classroom as well. I have taught and will teach a course at Brandeis in the English Department on twentieth century American bestsellers. In this course we are reading Babbitt, which I recommend if you haven't read it lately. Many of us haven't read it since high school, though it's actually a very good book. One of the things that Babbitt talks about is the rise of the professional class in America. It's very interesting on that subject, and I'll come back to that in just a moment.

In my December 2005 talk on "pubrarians" and "liblishers," I made a number of points, but at that time I was principally noting the overlap in the activities of academic publishers and research libraries. At the end of the talk I called for the intentional development of cross-trained professionals who would have education and experience in both professions: librarianship and publishing.

Library publishing, according to the Library Publishing Coalition (LPC) website, is:

$[\mathrm{B}]$ ased on core library values and builds on the traditional skills of librarians. It is distinguished from other publishing fields by a preference for open-access dissemination, and a willingness to embrace informal and experimental forms of scholarly communication and to challenge the status quo.

That's not just a mission statement. That's also a statement of professional values and aspirations.

As I was looking at that, and looking at some of the reading that I was discussing with my class at Brandeis yesterday, I was struck by this passage in an article we were reading from a Modern Language Association (MLA) publication. This is an article about Babbitt, Mainstreet, Arrowsmith, Dodsworth, a set of novels in which Sinclair Lewis explores the rise of the professional managerial class. The author of the article, Michael Augspurger, who wrote this as part of his dissertation and had it published by Cornell University Press (Auspurger, 2001), had some very interesting things to say about this. The true professional ideal, he said, encouraged doctors, lawyers, engineers, scientists, ministers, and professors to approach their jobs as "callings" that demanded disinterested objectivity, devotion to public service, professional autonomy, and a rejection of material ambition. That's an interesting set of values to take as defining characteristics of the professional ideal. 
Elsewhere in this article, Augspurger talks about a split in the professional class and a bifurcation into what he calls "adversarial professions" and professionals who accommodate themselves to bureaucracy and capitalism. I think one of the challenges we have in the library publishing world is that split. We have two groups of professionals in the room. One of them is perforce accustomed to interacting with market places, to dealing with money, and to selling things. The other does not have that as part of their job description and feels vaguely queasy about those roles. I think that divide is one of the humps that we have to get over in order to work together effectively. We have to recognize that really, if you are in academic publishing, you have a fair claim to have rejected material ambition. I mean, really.

Having accepted that, I think other intersections between the professions of librarian and publisher become easier to see, for example, that publishers, like librarians, consider their work in the service of the public. Not only are they not doing it to get rich, they are doing it because they think it is a good thing to do. In fact, if somebody hadn't, against all odds, published that dissertation as a book, I wouldn't have found that very interesting article that really illuminated a whole book and in some ways is becoming a centerpiece for the class that I'm teaching. I think we have more of these professional values in common than we generally allow.

Flash forward, from December 2005 or January 1995, pick your starting point, to February 2014 and to an Against the Grain article: "University Presses Facing Enormous Tectonic Shifts in Publishing" (Herther, 2014). This has also been a theme for the last twenty years or so of my life in the academy: there is a crisis in the humanities, there is a crisis in scholarly publishing, there is a crisis in the university. The only strange thing about this crisis is that it doesn't go away. It never concludes. Usually, there is some point at which the crisis is over. This crisis seems to have become our mode of being.

In the article, Nancy Herther (University of Minnesota Libraries) provides a nice roundup of up-to-the-moment activities and perspectives. It quotes Sarah Lippincott and others involved with the Library Publishing Coalition, and others like Doug Armato and Sandy Thatcher from the university press world. There are good voices, some very interesting perspectives. It's a nice compilation of markers of the current moment.

One of the things that we learn in Herther's piece is that there are now more university presses who are reporting through their libraries, or as part of their libraries, and that 60 libraries now belong to the Library Publishing Coalition. Brandeis belongs to both of those categories. Brandeis, is a Contributing Member of the Library Publishing Coalition, and as of last spring, the Brandeis University Press, which had reported through the president's office, is now reporting through the library. 
The story of how the press came to report through the library is instructive. I got a call from one of my more senior managers in the president's office who said, "This press, do we need it?" I said, "Give it to me and you won't have to worry about it. I'll take care of it." The Brandeis University Press is, in my view, an incredibly important part of the Brandeis brand out in the world. It defines us in some scholarly circles, and it is also part of the critical research infrastructure for the humanities and for the social sciences at Brandeis.

Brandeis is unusual, among university presses, in the way that it is grounded in the campus. It is integrated; series editors come from institutes on campus in many cases. It's more connected to campus life and activity than university presses sometimes are. I take that as a good sign and it is one of the reasons that I wanted to adopt the press.

I think one of the challenges that university presses have is that their activity is essentially altruistic from the point of view of the university and the funders. It is easy to see why you would give a library money and not expect them to give you money back. You give the library money because they procure collections and resources, which are used by your local constituency. It's not at all clear in the same way that university presses provide a local good, and therefore the logic of subsidy is a lot more difficult. One of the things I hope for with the Library Publishing Coalition is that we can change that calculus as more presses and more libraries start to work together. I hope that there will be seen to be local goods-not just forms of vanity publishing - that accrue to the campus as a result of having a press.

I am hopeful, but we haven't quite figured it out. Libraries, having been subsidized to produce a local good, don't want to charge people for information. That seems like double dipping somehow. University presses, who honestly believe in the value of the content they are producing, don't want to think that people might pay for the format in which that content is delivered. And that's not just university press publishers; I think that is true of publishers everywhere. It's a little bit of an insult to think that if somebody could get the intellectual content of a thing for free, that they would pony up nine dollars for an ebook format just because they like reading on their Kindle. But, in fact, that is how people behave. And nobody in this picture is fully funded for innovation, much less for altruism. We need to grapple with those issues.

There is a saying often attributed to Einstein (though it probably originates with William Bruce Cameron's 1963 book Informal Sociology), "Not everything that can be counted counts, and not everything that counts can be counted."

With respect to the Library Publishing Coalition, it began by focusing on the libraries and even in cases where there were presses reporting through those libraries, taking those 
presses off the table in the initial headcount. When I asked about this, the reason given for excluding them is reasonable, I think: to enable direct comparison across library programs, including those who do not work with a university press. And because the press often operates independently in terms of acquisitions, production, et cetera, from other library publishing activities, even if it is housed within the library.

All true. It is very reasonable to want to compare apples to apples, especially in the early stages of defining a new kind of activity and disseminating best practices. Still, I am happy to see many publishers here and happy that subsequent conversations with people at the Library Publishing Coalition have made it clear that library publishing can also be an activity see to include those university presses that report up through libraries. This is from Sarah Lippincott in Nancy Herther's Against the Grain article:

Monograph publishing has been a fruitful area of collaboration between libraries and university presses. In one collaborative model, the press contributes editorial expertise and distribution mechanisms for print media, while the library provides sophisticated technology for digital versions of the monograph or supplemental material.

I think it is telling that in much of what the Library Publishing Coalition says about publishers, publishers are defined in some ways as an earlier version of themselves. Publishers do print, they are not interested in open access, and they do distribution mechanisms and things like that.

I think there is a lot that library publishers can gain from working with university press publishers. It's critical to recognize that university press publishers are no longer just about print-far from it. University press publishers are also no longer opposed in some categorical way to Open Access. Like the rest of us, I think, they are trying to figure out how to make this work.

I think there is good value in sharing experience with other people who are starting to do something that you are starting to do. But I think ultimately as a community that involves both libraries and university presses, at some point we will want to step back far enough to measure and value the activity regardless of the actors.

In my 2005 talk, I noted a few things about the parties here. There are some things that publishers do that librarians have not traditionally done. Now, there are people in this room who come from relatively venerable library publishing operations and would be able to produce examples of some of these activities, but by and large, these are things that have characterized the profession of publishing and the activity of publishing. 
Libraries have a separate set of things that they do that haven't overlapped much with things that university presses do. Some of these activities have changed quite a bit in the last ten to fifteen years. We don't select in the same way that we used to in libraries, for example. We don't do as much original cataloging. But these are still activities that are deeply embedded in the professional identity of librarians.

So, if we did work together, deliberately, what could we do?

One thing we could do is to educate and train "pubrarians," cross-trained professionals in publishing and libraries. The Library Publishing Coalition is involved in an effort that is focused at the University of Illinois to work with that iSchool to develop such a program. I would be very interested in seeing that. In my 2005 talk, I listed a whole bunch of courses then in the curriculum that would be directly applicable to the activity of publishing. I'm not going to bore you with that list, but it would be longer now than it was before. We have a lot of faculty, especially in the online LEEP program at Illinois, ${ }^{1}$ who come from some different parts of the world of (especially) electronic publishing. A lot of those pieces are in place and it's great to see an effort afoot to actually pull them together under the heading of a certificate or a degree.

We also have some problems that we may be able to address together as librarians and publishers. Some of these are problems I identified in 2005, but that are still relevant today. When we go back to 2005, it gets brown and old looking. There is no business model for preservation by publishers. This is a long story, actually. Publishers have been melting down plates forever. It's just not their business to keep them around after they have outlived their usefulness for production.

There is no mission in libraries to work with authors. Some libraries have worked with faculty who are editing journals, or doing other things, but we aren't used to working with authors as producers in the way that publishers do.

Publishers aren't particularly trained in the organization and collection of information. Within certain boundaries and activities they do this, but it's a particular view of the activity. And librarians aren't trained in marketing, graphic design, or business. Again, in certain domains, they do things that look like that, but it's not a core part of their business.

There are "pubrarians" out there. By and large in 2005, and probably to a lesser extent but still today, you will find the majority of them in commercial publishers. University

\footnotetext{
${ }^{1}$ http://www.lis.illinois.edu/future-students/leep
} 
presses are in this game only if they are collaborating with their libraries, partly because this is a question of infrastructure and who has capitalized to have it. The particular kind of infrastructure involved here is more likely to be found either in commercial publishing or in libraries than in university presses.

Commercial publishers are capitalized for new ventures. They spend money to develop products in advance of the market. And that's good, if you are a commercial publisher. It's not so good if you are a university press and you are trying to compete at some level with people who are capitalized in some way and can do new things.

When I was at Illinois we had a conversation that didn't really develop the way that I had hoped it would. Some people in this room were probably part of that conversation. It involved, at each of several campuses, the director of the university press, the dean of the iSchool, the director of the library, and the provost. The purpose of these conversations was to figure out if across a number of major state universities, all CIC universities, we could agree to capitalize the development of new research services around data communities that we could identify.

One of the interesting things that emerged in that conversation was that all of the parties at each of the universities had basically only local constituencies, except for the presses. The presses were the only people in the room who worked with communities of scholars across universities where their communities were defined by discipline or area of interest. You could think of it as list building, but it's also community building.

Everybody else was focused on the campus constituency. These conversations eventually broke down, in part I think, because the presses and the libraries couldn't quite figure out how they were going to work together. I still think the notion of developing advanced research services for data communities in an academic setting is a very legitimate, interesting target for a group like this and is doable if we can figure out our respective roles.

In the last part of this talk, I'm going to give you a few different examples of opportunities to get at some of this. These are all things that I'm involved with in one way or another so I make no pretense of disinterest, but they are also things that I know reasonably well as a result of being involved.

The first thing I will talk about is the HathiTrust Research Center. This offers the opportunity to develop and serve data communities without a lot of redundant infrastructure. There is so much data being pooled in the HathiTrust, not just from the Google Books projects, or things that libraries themselves have digitized, but from multiple sources, as you'll hear when I talk about Knowledge Unlatched. 
In some real way it represents the contents of an ideal research university library. There are three billion pages on all subjects and in many languages, about half in English. There is a ton of opportunity, and the fact that the basic infrastructure exists removes a huge barrier to innovation for this community. With the infrastructure in place, we now only need to figure out how to build services on top of that infrastructure.

The University of Illinois has just started a grant from Mellon: a sort of re-granting operation to work with specific projects that are interested in developing a clearer understanding of a corpus in the context of these huge collections. If you are working with three billion pages, you aren't working with three billion pages. No one can work with three billion pages. You are working with some subset of that very large collection. So how do you cut through the mass of stuff to get the subset that interests you? How do you manipulate that subset of data once you have it, how do you share results? How do you share your data, just the selected set, with other people? What happens as that dataset goes through its life cycle, and what are its parts? Are they different in different disciplines? Are they different in different languages? How do we understand this fundamental building block of scholarly work in the presence of big data?

So I see the HathiTrust Research Center as a laboratory for exploring new research needs and opportunities. I see it as a place where we will partner in some ways with academically oriented commercial publishers like Gale and ProQuest. I think the incentive for them is that people already come to them on a regular basis asking for datasets. They want to be helpful, and they want to know what people are doing with these datasets, because they are interested in understanding the behavior of clients.

They generally try to provide these datasets, but they do so with no guarantee that they will ever hear back about what happened, no guarantee that the agreement to destroy the data when the research is done will be upheld and a fair amount of staff time spent manually assembling the datasets that are required. I can see a business case for a commercial publisher to put its data in the HathiTrust and to ask the research center to be in charge of providing researchers with those datasets.

Part of this discussion is the issue of rights management. We are very excited in the HathiTrust Research Center to be working through the final stages of a security review at Illinois and at Indiana with oversight from Michigan. That is a necessary step on the way to our being able to provide people with computational access to the copyrighted material that is in the HathiTrust. That is the 75 percent of material that you can't get at under any circumstance right now. Managing those rights, like building the infrastructure, is a huge undertaking that could swamp any of our efforts to build services on top of that. 
The HathiTrust's matrix of rights gives a sense of the enormity of this endeavor. Across the top of this matrix is the type of work, whether it is searchable as bibliographic information and full text, whether it is viewable, whether you can download a full PDF, whether it's available to the data API, whether it can be printed on demand, whether it can be made available to people with print disabilities, and whether it has preservation uses.

Down the left hand column are types of work. For example, one type is public domain worldwide. That's the least problematic stuff. It's about 10 percent of the total. Continuing down this column, we have public domain in the U.S.; non-U.S. works published between 1872 and 1923; works that rights holders have opened access to HathiTrust; where rights are known and the right holder has made the work open access; works that are in copyright or of undetermined status (including the difficult category of orphan works).

And then, where are these conditions obtained? Is public domain worldwide searchable? Yes, worldwide. Is it viewable? Yes, worldwide. Are works that are public domain in the U.S. and non-U.S. works published between 1872 and 1923 searchable? Yes, worldwide. Viewable? When accessed from the United States. All of these conditions have different switches depending on who is looking at them and what they are looking at. There is an infrastructure for dealing with this, and there is a way of identifying materials as belonging to these categories. That in itself is a huge boon-a move towards being able to do work without ending up in court, or let's just say, without ending up in court very often.

This is infrastructure that you don't want to have to build. This is high performance computing hooked up to data stores that are provided to the research center from the HathiTrust and various processes, authentication, passing algorithms back and forth across fire walls, et cetera. It's great stuff not to have to do.

Why would we do those things? Here are some of the actual interesting questions that we get, things that people want to do with this data. I see lots of opportunities here for us, collectively. Can we identify all the works that deal with Francis Bacon? What musical scores are in the corpus? What works contain music notation? Which works have back-ofbook indexes that I might analyze? How would I gather works by sixteenth century women? By nineteenth century men? Which works are fiction? Which are nonfiction? Which are essays? Poetry? How would I gather works similar to those that I currently have in hand? Can I define different kinds of similarity?

We didn't make up those questions. Those are real questions that real researchers have, and you can see an implied research program behind those questions. All of these questions are, in principle, answerable. They are all questions that you can't answer right now with existing 
metadata. Even though, like in the MARC record, there is a place to identify genre, we don't currently do that when we catalog things. The gender of the author, likewise.

There are interesting computational ways to deal with some of these problems. There are all kinds of things to be learned by trying to answer questions like this. I think a combination of publishers, who work with authors, and libraries, who support scholarly research, is a good group to be working with some of these questions.

My second example is the University Press of New England. One of my reasons for accepting the invitation to come here and talk to you is that I really see a strong opportunity here for library publishers. I understand that the focus in library publishing is and should be on Open Access. That implies electronic distribution for free.

However, given that we know that people will pay for format, why not offer people the chance to pay for what they can also get for free and see what they do? Why not work with a group like the University Press of New England who has a large program of publishing services and affiliates, and say, "These titles seem like they might work ... you take them and make them into ebooks, get them up on Amazon, iTunes, all the distribution channels that you already work with, and let's see what happens. And while you are at it, if someone wants print, make it available so they can print on demand. We think it will be too expensive, but, you know, let's see what happens."

I think there is enough interest in format to potentially make certain kinds of open access sustainable in economic terms, if we don't deliberately cut off that market. This is what the University Press of New England is focusing on at the moment in terms of list building. They have both general interest and academic lists, and they have an interest in books for course adoption. Some of the topics here might chime with some things that you are considering doing in your own library publishing operations. If so, there might be some advantage to having those titles available to be found where people are finding other titles on those subjects.

But these are really what the UPNE focuses on in their work with publishing affiliates. The topics are at the discretion of the affiliate and cover a very large range. The UPNE provides a range of services such as manuscript editing and book design; project management; domestic and Asian print brokering; ebook production conversion; and national and international distribution to major channels including Kindle, Nook, iBooks, and library ebook aggregators; financial management and business operations; metadata management; book marketing and publicity; book sales; order entry; customer service; warehouse and fulfillment including print-on-demand coordination. 
As a library, those are a lot of things that I don't want to learn how to do, and I would be very happy not to have to do them. But I wouldn't mind print-on-demand in Asia or international ebook distribution. That would be great. Ebooks are kind of the heart of the matter, at the moment. This is Doug Armato from the Against the Grain article: "The ebook transition has been a major hurdle, but it is well underway."

The biggest challenge in the academic library market is that it hasn't transitioned to electronic fast enough, and presses are still running parallel print and digital systems for library products, which is costly. From the library side, the advent of ebooks has been overwhelming and confusing. Brandeis is part of an ebook pilot project in the Boston Library Consortium where we negotiated prices with several publishers. No two publishers price their ebooks the same, incidentally. It's enough to make you pine for Amazon.

Pricing is all over the map. Publishers will offer you terms like, "four people can view it, and then the fifth person that looks at it, you've bought the book." But another publisher will have different terms. It's the overhead, and just figuring out what you are buying in some of these ebook deals is kind of staggering.

I don't think it's that libraries aren't interested in ebooks. They are interested in what their patrons want, and increasingly, people want ebooks. Also, libraries are and have always been interested in technological innovation. So they aren't averse to this. But it hasn't been easy to figure out how to work with it. At the same time, I think Doug Armato is absolutely right that running parallel systems is expensive and if you don't have a system that seamlessly produces multiple outputs with a single input, it ups your cost of doing business.

My third and final example is Knowledge Unlatched. Again, many people in the room participate in Knowledge Unlatached and are aware of it. I've been looking at things like this since I got to Brandeis. I've spent some time speaking to the Unglue.it people. Unglue. it is a kind of Kickstarter model for making titles open access. It's great, but it doesn't work with library budgeting. It's great if you are an individual, but libraries couldn't plan a budget around Unglue.it to save their lives.

Knowledge Unlatched, on the other hand, has really taken that problem and solved it in a very clever way. It represents an interesting collaboration between libraries and publishers. There is a group of libraries that selects titles offered up by publishers, and that selection is licensed as a bundle and sold to participating libraries. Once the publisher has earned back the title fee, which the publisher gets to set, then the book becomes open access with a Creative Commons license. 
In this way libraries could see their subscription budget as buying books out of bondage, and that's attractive. And you can budget it. The open access infrastructure for distribution is OAPEN in Europe and the HathiTrust.

Knowledge Unlatched addresses a number of problems that publishers face. With more titles and fewer sales, there is more risk per title for publishers. If you contribute a book to Knowledge Unlatched as a publisher, you have basically zero risk. In fact, on average you are likely to have better results with that book than with your other titles because you have a guaranteed source of income for it, and there are typically no guarantees in publishing.

Secondly, monograph sales are being squeezed out of library budgets by journals. Libraries need to figure out how to increase open access to monograph materials. What we've been doing so far is providing funding for authors to pay page charges, which is okay in the sciences, but it does nothing for you in the humanities and social sciences. It's just not a model that works there. Some title fee examples from Knowledge Unlatched: if you have a $\$ 10,000$ title fee, and there are 250 libraries participating, the cost per library for the title is 40 dollars. Forty dollars is not an unreasonable price to pay for a monograph.

If you have 750 at that 10,000 title fee, it is 13 bucks. That's a deal. I think these title fees are realistic, from looking at the Brandeis University press. They are in the realm of reality. To think that, with a few hundred libraries participating, this could be sustainable year in and year out, and every year would provide more open access monographs in the humanities and the social sciences, is really encouraging. I applaud Knowledge Unlatched for having cut this particular Gordian knot.

Next, I'll offer some thoughts on opportunities for the Library Publishing Coalition.

One is engaging the digital humanities. Going back to trying to publish the Rossetti Archive with the University of Michigan Press, we still really haven't figured out how to publish born-digital humanities scholarship, and it's still out there. Before I left, I helped the university press at Virginia start Rotunda, which is a pretty successful experiment in this kind of publishing, but there are not a lot of them, and there is plenty of room to do more in that area.

A second is supporting data communities, which I mentioned before. I think that is a very real possibility right now, and one that we should jump on. Other people certainly will.

The third is the publication and curation of gray literature. A lot of important scholarship and communication goes on in the form of conference proceedings. I'm involved with 
the Alliance of Digital Humanities Organizations, which puts a great deal of care into its conference proceedings every year, and it is a publishing operation that they do, year in and year out, because they want to preserve that record.

The fourth way is publishing faculty-edited journals that experiment with new business models and promote sustainable Open Access. Those are all things that I think are on the table that we could be doing together.

And, because I came out of an English PhD program in the early 1980s, I have to end with deconstructing some binary oppositions for you.

Libraries versus publishers: that one is breaking down, isn't it?

Open access versus commercial: one of the things that I learned early on about the University Press of New England that interested me in knowing more about them was that they had done a simultaneous open access and on-demand ebook publication in classics, of all fields, and that it had been a success.

The opposition of print versus electronic: problematic. Everything is electronic to begin with, some things are electronic at the end, some things are print in the middle. I don't think we should be slicing our world according to those oppositions.

Experimental versus traditional: traditional is becoming increasingly experimental. But I think it's in the nature of professional values and professional behavior to embrace both of those things. We know why our traditions are what they are; why we value some of the things that we do, not because they are traditional, maybe in spite of the fact that they are traditional, but we value them because we understand that they are important. We shouldn't put them aside because they have that label.

Research versus publication: much more of a continuum now than it used to be. I think maybe it was always more of a continuum than it seemed, but a lot of that continuum was hidden from view-people writing letters to each other. The kind of communication and development of ideas that takes place now, on the way to publication, is much more public. It is done on blogs. It's done in various online forums. The moment of publication: that is an interesting problem. When did you publish that idea? When it came up in a blog entry? When you published it in an ebook?

Last but not least: this is one that I think will be one of the more difficult ones to tackle, but the opposition between vanity publishing and scholarship, where vanity publishing is 
defined as publishing at home and scholarship is defined as publishing abroad. That one we have to get around, and I don't know how we do that other than by addressing it head on. If you are at a university that has a library publishing operation or a university press operation, publishing with your local publishers should not be a stigma. It should assume the same level of peer review that characterizes whatever else goes through those channels, and we need to get past this in order to, for one thing, bring a little more of the logic of local goods and the subsidies for local goods to bear on our publishing operations.

So, that's it. I'll see you all again in 10 years.

\section{REFERENCES}

Augspurger, M. (2001). Sinclair Lewis' primers for the professional managerial class: Babbitt, Arrowsmith, and Dodsworth. The Journal of the Midwest Modern Language Association, 34(2) 73-97.

Herther, N. K. (2014, February 17). University presses facing 'enormous tectonic shift' in publishing. Against the Grain. Retrieved from http://www.against-the-grain.com/2014/02/an-atg-original-universitypresses-facing-enormous-tectonic-shift-in-publishing/ 